Каймак Е.B.

\title{
ПРАВОВЫЕ ОСНОВЫ БОРЬБЫ С ОРГАНИЗОВАННОЙ НАРКОПРЕСТУПНОСТЬЮ ВО ВЗАИМОСВЯЗИ С СИСТЕМОЙ ОБЩЕСТВЕННЫХ ОТНОШЕНИЙ
}

\begin{abstract}
Аннотация: B статье рассмотрены правовые основы борьбы с организованной преступнстью в сфере незаконного оборота наркотиков в наркопритонах. Изучению организованных форм преступности в целом, как негативного соииального явления и организации борьбы с ним посвятили свои труды многие ученые. Вместе с тем организованная преступная деятельность, связанная с организацией либо содержанием наркопритонов, как системныій элемент общественных отношений, характеризующийся внутренними и внешними связями, ранее на монографическом уровне криминологически не исследовалась. Предметом исследования стали механизмы функиионирования организованных групп, преступных сообществ (преступных организащий), связанных с организацией либо содержанием наркопритонов, преступная деятельность таких формирований и их участников, а также возникающие в ходе преступной деятельности системные внутренние, внешние взаимодействия и их изменения под влиянием различных мер реагирования. Исследование правовой природы, связанной с организаииейлибо содержанием наркопритонов, а также имеюшихся в этой связи правовых пробелов и проблем правоприменительной практики представляется актуальным для дальнейшего совершенствования борьбы с данным негативным соииальным явлением. Объект исследования составили организованные группы, преступные сообщества (преступные организаиии), связанные с организацией либо содержанием наркопритонов, и их деятельность. На основе проведенного исследования организованной преступности в данном ее проявлении определены направления оптимизации борьбы, в том числе на законодательном уровне. Review: The article is devoted to the legal grounds of struggle against organized crime in the sphere of illegal drug trafficking in drug dens. Many researchers have dedicated their work to studying organized forms of crime as a negative social phenomenon and associated response measures in general. However, organized criminal activity related to creation or maintenance of drug dens as a system element of social relations with internal and external communications has not been studied in a form of a monograph before. The subject under review is the functioning mechanisms of organized groups and criminal communities (associations) that are related to creation or maintenance of drug dens, criminal activity performed by such organizations and their participants, internal and external interactions arising in the course of such criminal activity and changes thereto under the influence of different response measures. The study of the legal nature of phenomena related to creation or maintenance of drug dens as well as particular gaps in applicable legislation and problems of law enforcement practice appears to be important to further struggle against this negative social phenomenon. The object of research is the organized groups, organized communities (criminal associations) that are related to creation or maintenance of drug dens and teir activity. Based on the results of the research, the author defines directions for improving the struggle against organized drug-related crime including undertaking certain measures at the legislative level.
\end{abstract}

Ключевые слова: общество, организованная преступность, притон, наркотические вещества, психотропные вещества, правонарушение, криминал, нарушение закона, оборот наркотиков, правоохранительные органы.

Keywords: society, organized crime, drug den, narcotic drugs, psychotropic substances, violation, criminality, violation of law, drug trafficking, law enforcement authorities.

$\mathrm{H}$ ормативную правовую основу борьбы с организованной преступной деятельностью, связанной с организацией либо содержанием притонов для потребления наркотических средств, психотропных веществ или их аналогов (далее - наркопритоны), составляют федеральные конституционные законы, федеральные законы, законы Российской Федерации и иные нормативные правовые (подзаконные) акты, различная сфера регулирования которых однозначно свидетельствует, что борьба с организованной преступностью в данном ее проявлении, выходит за пределы уголовной политики.

Для эффективного воздействия на причинный комплекс, порождающий организованную преступную деятельность, связанную с организацией либо содержанием наркопритонов, необходима адекватная развитию ситуации система правового регулирования борьбы. 
С.Д. Белоцерковский, ${ }^{1}$ исследовавший систему правового регулирования борьбы с организованной преступностью в целом, предложил классифицировать нормативные правовые акты, составляющие правовую основу борьбы, по следующим трем основаниям:

«А) Федеральные законы, содержащие нормы об ответственности за совершение административных проступков и уголовных преступлений, регулирующие порядок их выявления, предупреждения, пресечения и раскрытия, выявления и установления лиц, их подготавливающих или совершивших, регламентирующие процедуры доказывания, привлечения к ответственности, осуждения таких лиц, исполнения в отношении них уголовного наказания, а также федеральные законы о защите должностных лиц, участвующих в борьбе с организованной преступностью, судей и участников уголовного судопроизводства.

Б) Федеральные законы, определяющие организацию, компетенцию и порядок деятельности правоохранительных органов, участвующих в борьбе с организованной преступностью.

В) Федеральные законы о противодействии отдельным видам преступности, которые имеют организованную основу или непосредственно связаны с организованной преступностью.».

Результаты криминологического исследования показывают, что предложенная классификация нормативных правовых актов, формирующих правовую основу борьбы с организованной преступностью в Российской Федерации, применима при классификации нормативных правовых актов, регламентирующих борьбу с организованной преступностью, связанной с незаконным оборотом наркотиков в наркопритонах. ${ }^{2}$ В рамках классификации нормативных правовых актов, составляющих систему правового регулирования

\footnotetext{
1 Белоиерковский С.Д. Система правового регулирования борьбы с организованной преступностью и научные основы ее оптимизации: Монография. - М. : Российская криминологическая ассоциация, 2011. 257, 258, 392 с.

2 Под деяниями, связанными с незаконным оборотом наркотиков в наркопритонах, понимаются взаимосвязанные и взаимообусловленные преступные деяния: организация либо содержание наркопритонов (статья 232 Уголовного кодекса Российской Федерации), незаконное производство наркотиков для последующего сбыта в наркопритонах либо сбыт наркотиков в наркопритонах (статья 228.1), контрабанда наркотиков (статья 229.1), хранение оптовых поставок наркотиков и незаконная перевозка в наркопритоны (статья 228), склонение к потреблению наркотиков (статья 230) и другие деяния.
}

борьбы с организованной преступностью в данном ее проявлении, приведенную систему лишь целесообразно дополнить новой группой:

«Г) Нормативные правовые акты, содержащие нормы, составляющие систему воздействия на процессы детерминации и причинности организованной преступности, связанной с организацией либо содержанием наркопритонов».

Схема 1. Система правового регулирования борьбы с организованной преступностью (С.Д. Белоцерковский), дополненная в аспекте борьбы с незаконным оборотом наркотиков в наркопритонах

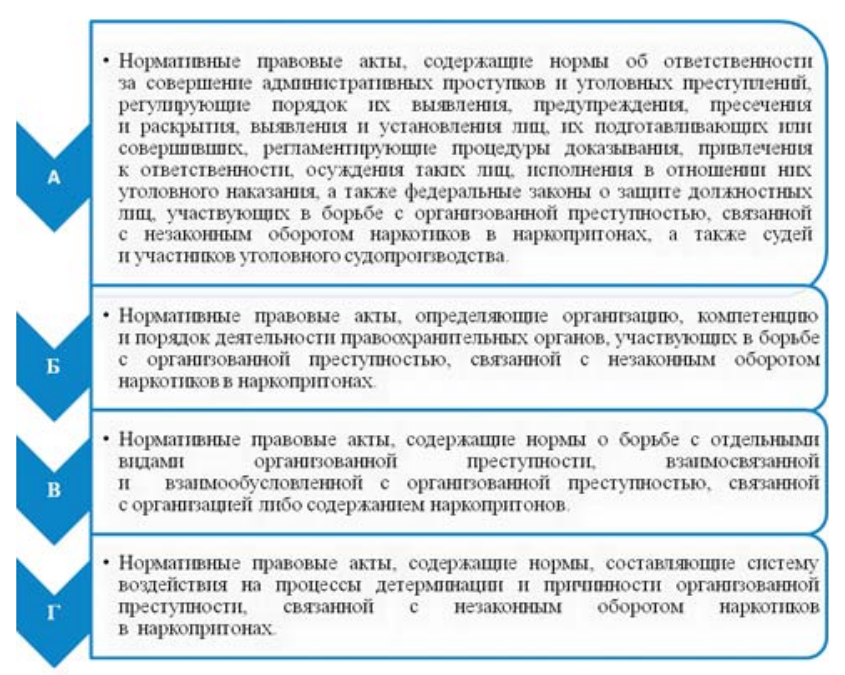

Указанное дополнение необходимо, так как во многом именно пробелами в нормативных правовых актах, составляющих систему воздействия на процессы детерминации и причинности организованной преступности, обусловлена низкая эффективность борьбы на данном направлении.

Новый подсистемный элемент «Г» характеризуется следующим содержанием:

- Основные федеральные законы:

№ 323-Ф3 от 21 ноября 2011 г. «Об основах охраны здоровья граждан в Российской Федерации»;

№ 436-Ф3 от 29 декабря 2010 г. «О защите детей от информации, причиняющей вред их здоровью и развитию»;

№ 120-Ф3 от 24 июня 1999 г. «Об основах системы профилактики безнадзорности и правонарушений несовершеннолетних»;

№ 115-Ф3 от 25 июля 2002 г. «О правовом положении иностранных граждан в Российской Федерации»; 


\section{Политика и общество 4 (112) • 2014}

№ 2124-1 от 27 декабря 1991 г. «О средствах массовой информации».

- Основные подзаконные нормативные правовые акты Российской Федерации:

постановление Правительства Российской Федерации от 20 июля 2011 г. № 599 «О мерах контроля в отношении препаратов, которые содержат малые количества наркотических средств, психотропных веществ и их прекурсоров, включенных в перечень наркотических средств, психотропных веществ и их прекурсоров, подлежащих контролю в Российской Федерации»;

распоряжение Правительства Российской Федерации от 24 декабря 2012 г. № 2511-р «Об утверждении Государственной программы «Развитие здравоохранения».

- Основной межведомственный нормативный правовой акт:

приказ Минздрава СССР и МВД России от 20 мая 1988 г. «Об утверждении Инструкции о порядке выявления и учета лиц, допускающих немедицинское потребление наркотических средств или других веществ, влекущих одурманивание, оформления и направления на принудительное лечение больных наркоманией (с изменениями, внесенными приказом МВД России от 30 июня 2003 г. № 492).

- Основной нормативный правовой акт Федеральной службы Российской Федерации по контролю за оборотом наркотиков:

приказ ФСКН России от 2 ноября 2012 г. № 440 «Об организации работы в ФСКН России по принятию решений, являющихся основаниями для включения доменных имен и (или) указателей страниц в сети «Интернет», а также сетевых адресов в «Единый реестр доменных имен, указателей страниц сайтов в информационно-телекоммуникационной сети «Интернет» и сетевых адресов, позволяющих идентифицировать сайты в информационно-телекоммуникационной сети «Интернет», содержащие информацию, распространение которой в Российской Федерации запрещено».

- Основные нормативные правовые акты иных федеральных органов государственной власти:

приказ Минздрава СССР от 12 сентября 1988 г. № 704 «О сроках диспансерного наблюдения больных алкоголизмом, наркоманиями и токсикоманиями»;

приказ Минздравсоцразвития России от 9 апреля 2010 г. № 225 ан «Об утверждении порядка наркологической помощи населению Российской Федерации»;

приказ Минобрнауки России от 12 апреля 2011 г. № 1474 «О психологическом тестировании обучаю- щихся образовательных учреждений, реализующих общеобразовательные программы основного общего, среднего (полного) общего образования и профессиональные программы начального профессионального, среднего профессионального и высшего профессионального образования, на предмет потребления наркотических средств, психотропных веществ и других токсических веществ».

В настоящее время существует целый ряд проблем, связанных с необходимостью совершенствования действующих либо разработки новых нормативных правовых актов, составляющих правовую основу борьбы с организованной преступностью, связанной с незаконным оборотом наркотических средств, психотропных веществ или их аналогов (далее - наркотики) в притонах. При этом меры по оптимизации российского законодательства целесообразно рассматривать с учетом приведенной классификации нормативных правовых актов.

В частности, в группе «А» нормативных правовых актов в аспекте деятельности по совершенствованию правовой основы борьбы с организованной наркопреступностью наиболее актуальными являются следующие направления.

Прежде всего, необходимо отметить, что в Российской Федерации отсутствует комплексный закон о борьбе с организованной преступностью, который предусматривал бы применение к участникам организованной преступной деятельности не только меры уголовно-правового воздействия, но и предупредительные меры, необходимые в рамках системного подхода к борьбе с организованной преступностью во всех ее проявлениях. Ключевыми проблемами борьбы с организованной преступностью, связанной с незаконным оборотом наркотиков и характеризующейся транснациональными связями, требующими законодательного решения, являются:

совершенствование правовой основы борьбы с лидерами транснациональных преступных организаций, управляющих наркопотоками и наркоденьгами непосредственно с территории иностранных государств;

совершенствование нормативных положений, регламентирующих понятийный аппарат об организованной преступности в различных формах ее проявления («организованная преступная деятельность», «транснациональная организованная преступная деятельность», «преступные сообщества», «преступные организации» и другие). Так, сегодня многие ученые обоснованно поднимают вопрос о 
том, что преступные сообщества и преступные организации - это различные по своей преступной сущности организованные преступные формирования с различными целями и задачами.

На российском правовом пространстве в связи с совершенствованием правовой основы борьбы с организованной преступной деятельностью, связанной с незаконным оборотом наркотиков в наркопритонах, актуальными остаются вопросы совершенствования уголовного закона. Так, действующая редакция статьи 63 «Обстоятельства, отягчающие наказание» Уголовного кодекса Российской Федерации не предусматривает в качестве отягчающего обстоятельства совершение преступлений в присутствии либо по месту проживания несовершеннолетних. Наоборот, наличие малолетних детей у виновного, согласно статье 61 «Обстоятельства, смягчающие наказание» Уголовного кодекса Российской Федерации, является смягчающим обстоятельством.

В этих правовых условиях действия, как следствие, приводящие к формированию у несовершеннолетнего криминальных установок не подлежат адекватной юридической оценке. Согласно результатам исследования преступления, предусмотренные статьей 232 Уголовного кодекса Российской Федерации, совершаются в основном лицами, не состоящими в зарегистрированном браке (50\%), но при этом имеющими на иждивении 1 или 2-х детей, которые растут в условиях функционирующих наркопритонов.

Подтверждают данный вывод материалы уголовных дел, согласно которым для почти половины содержателей наркопропритонов, отметивших в ходе допросов наличие одного или несколько старших по возрасту родственников, потребляющих наркотики, данный фактор стал основным социальным детерминантом преступного поведения. В этой связи целесообразно совершение преступлений, связанных с организацией либо содержанием наркопритонов, совершенных в присутствии либо по месту жительства несовершеннолетних, рассматривать как преступления, совершенные при отягчающих обстоятельствах.

С учетом изложенного необходимо статью 63 Уголовного кодекса Российской Федерации дополнить новым пунктом следующего содержания: «совершение преступления в присутствии либо по месту проживания несовершеннолетнего».
Требует совершенствования редакция статьи 82.1 «Отсрочка отбывания наказание больным наркоманией» Уголовного кодекса Российской Федерации. Действующая редакция предполагает конкретный перечень статей Уголовного кодекса Российской Федерации, а именно, статьи 228, 231, 233, при совершении которых применяются положения статьи 82.1 Уголовного кодекса Российской Федерации. В настоящее время лишь осужденным к лишению свободы, признанным больными наркоманией, совершившим впервые преступления, предусмотренные частью первой статьи 228, частью 1 статьи 231 и статьей 233 Уголовного кодекса Российской Федерации, и изъявившим желание добровольно пройти курс лечения от наркомании, а также медицинскую реабилитацию, социальную реабилитацию, суд может отсрочить отбывание наказания в виде лишения свободы до окончания лечения и медицинской реабилитации, социальной реабилитации.

Преступления, предусмотренные статьей 232 Уголовного кодекса Российской Федерации, основанием для применения указанной статьи не являются, несмотря на значительный удельный вес наркопотребителей в общем числе лиц, совершивших преступления, которые в силу пагубной привычки становятся послушным инструментарием организаторов преступной деятельности. Ситуация обусловлена тем, что в целях предупреждения практики злоупотребления данным положением для ухода от уголовной ответственности при разработке статьи 82.1 Уголовного кодекса Российской Федерации учитывалась лишь категория преступлений небольшой тяжести, а действующая редакция части 1 статьи 232 Уголовного кодекса Российской Федерации составляет преступления средней тяжести, так как предусматривает санкцию до 4-х лет лишения свободы.

С учетом криминологических характеристик лиц, совершающих преступления, предусмотренные статьей 232 Уголовного кодекса Российской Федерации, целесообразно внести изменения в редакцию статьи 82.1 Уголовного кодекса Российской Федерации, заменив конкретный перечень статей уголовного закона на следующие категории преступлений всех составов уголовного закона: преступления небольшой и средней тяжести.

Среди проблем, связанных с необходимостью оптимизации нормативных правовых актов группы «Б», определяющих организацию, компетен- 


\section{Политика и общество 4 (112) • 2014}

цию и порядок деятельности правоохранительных органов, участвующих в борьбе с организованной преступностью, связанной с незаконным оборотом наркотиков в наркопритонах, актуален вопрос совершенствования нормативных правовых актов, регламентирующих организацию в правоохранительных органах учета лиц, совершивших административные правонарушения:

персональных данных лиц, совершивших административные правонарушения, связанные с немедицинским потреблением наркотических средств и психотропных веществ;

адресов помещений, использованных в целях содержания наркопритонов, с разбивкой на категории помещений, например, следующие: жилое помещение, помещение, используемое для массового досуга населения, помещение образовательных учреждений, помещение иного назначения.

Наркопотребление сегодня является одним из основных детерминантов, обуславливающих преступное поведение лиц, наращивание криминальной активности и профессионализма. В типичных криминальных условиях, когда наркопотребитель впервые совершает административные правонарушения, связанные с немедицинским потреблением наркотиков, затем преступления различной квалификации (сбыт наркотиков в целях получения бесплатной наркотической дозы либо кражи, грабежи и другие преступления общеуголовной направленности в целях получения денежных средств, необходимых для получения наркотической дозы) в федеральных органах исполнительной власти отсутствует единый порядок учета персональных данных лиц, совершивших административные правонарушения, связанные с немедицинским потреблением наркотиков. Как следствие, отсутствует организация эффективной индивидуальной профилактической деятельности, направленной на формирование у наркопотребителей позитивных социальных установок и их возврат в социум.

Наряду с указанным, различный подход к формированию баз статистических данных на ведомственных уровнях, как следствие, приводит к различному подходу на межведомственном уровне. Так, в межведомственной форме статистической отчетности разными органами государственной власти учитываются различные по полноте сведения о лицах, совершивших административные правонарушения, связанные с немедицинским потре- блением наркотиков, в части, касающейся вида наркотика, потребление которого вызвало состояние наркотического опьянения.

Необходимо отметить, что уголовная статистка о видах и массе изымаемых на территории оперативного обслуживания наркотиков не дает объективного представления о структуре наркорынка, так как во многом зависит от профессионализма сотрудников правоохранительных органов, уровня оснащения техническими и специальными средствами, иных внешних факторов и не учитывает уровня латентности (скрытости) наркопреступности. Между тем, сведения о структуре административных правонарушителей по видам наркотиков, вызвавших состояние наркотического опьянения, дает достаточно объективное представление о структуре наркорынка, что позволяет выработать более эффективные меры борьбы с данным негативным социальным явлением и адекватный прогноза развития ситуации на территории оперативного обслуживания.

Различная правовая основа учета персональных данных лиц, совершивших административные правонарушения, связанные с немедицинским потреблением наркотиков, приводит к различной организации профилактической деятельности на региональном уровне. Результаты исследования показывают, что в пределах отдельных субъектов Российской Федерации число лиц, за которыми организовано профилактическое наблюдение в связи с немедицинским потреблением ими наркотиков, не превышает 5\%. Между тем, эффективность лечения, реабилитации и ресоциализации наркопотребителей, состояние их здоровья в дальнейшем во многом зависит от принятия необходимых мер на раннем этапе наркопотребления.

Одной из причин, обуславливающей складывающуюся ситуацию, является отсутствие единого порядка информирования органов исполнительной власти Российской Федерации в сфере здравоохранения правоохранительными органами о выявленных фактах немедицинского потребления наркотиков, а также о лицах, условно-досрочно освобождающихся от наказания, проходивших лечение в лечебных или лечебно-профилактических учреждениях уголовно-исполнительной системы в связи с немедицинским потреблением наркотиков. На ниже приведенной схеме 2 указаны субъекты данной деятельности. 
Схема 2. Субъекты деятельности по информированию медицинских организаций государственной или мунищипальной систем здравоохранения о лицах, замеченных в немедицинском потреблении наркотиков

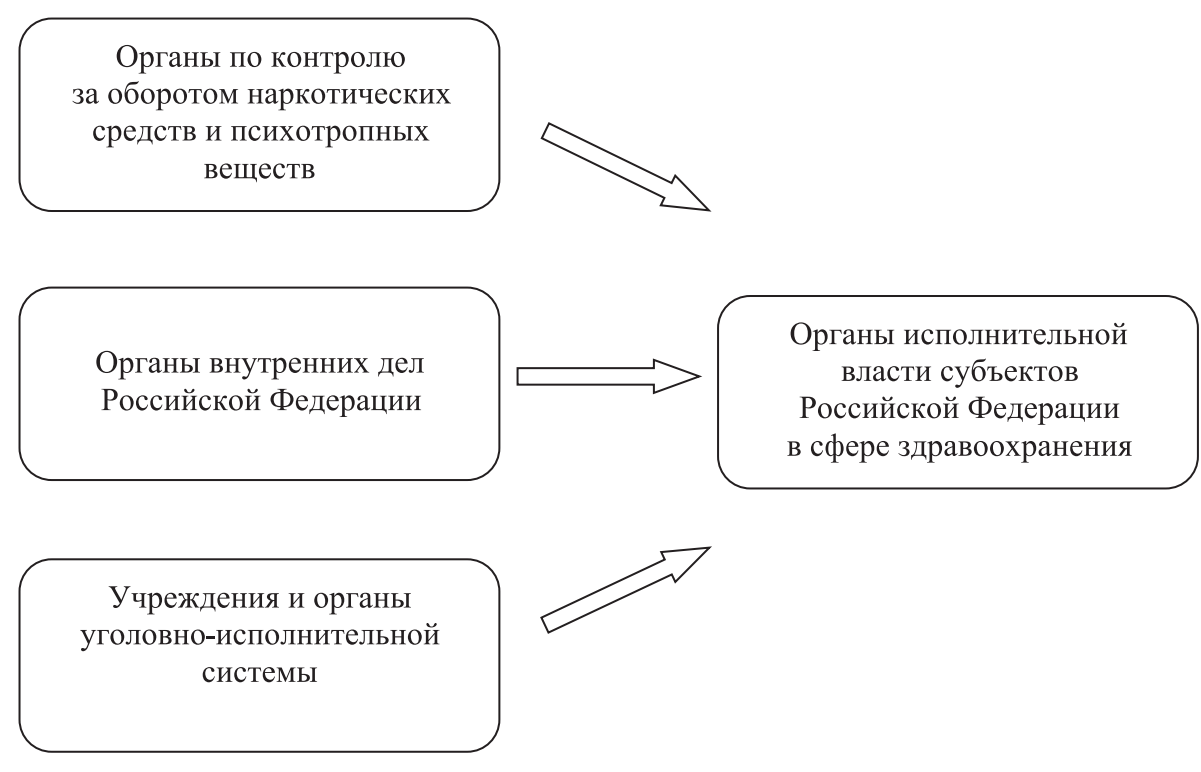

Имеют место иные правовые пробелы в рассматриваемом подсистемном элементе «Б».

В группе «В» нормативных правовых актов, содержащих нормы о борьбе с отдельными видами организованной преступности, взаимосвязанной и взаимообусловленной с организованной преступностью, связанной с организацией либо содержанием наркопритонов, наиболее актуальным является вопрос совершенствования нормативной правовой основы борьбы с незаконным оборотом наркотиков с использованием средств массовой информации либо электронных или инфор-

Информация о лицах, допускающих немедицинское потребление наркотиков, должна незамедлительно направляться в органы исполнительной власти субъектов Российской Федерации в сфере здравоохранения для последующей работы с данной категорией населения в целях недопущения развития у них пагубной зависимости, а при ее наличии в целях принятия более широких комплексных мер, направленных на лечение, реабилитацию и ресоциализацию.

В аспекте учета административных правонарушений, связанных с немедицинским потреблением наркотиков, необходимо также отметить, что существующими формами в правоохранительных органах не предусмотрен учет сведений о лицах, повторно совершивших административные правонарушения данной квалификации. Вместе с тем результаты исследования показывают, что каждый наркопотребитель в течение года многократно совершает административные правонарушения, связанные с немедицинским потреблением наркотиков. В этих криминальных условиях сведения о частоте повторности совершения административных правонарушений с учетом вида потребляемых наркотиков могут быть одним из объективных показателей эффективности борьбы с межрегиональными и транснациональными каналами наркотрафика на конкретной территории оперативного обслуживания. мационно-телекоммуникационных сетей, прежде всего, сети «Интернет».

Сведения об использовании сети «Интернет» в организованной преступной деятельности, связанной с незаконным оборотом наркотиков в наркопритонах, впервые была отражены в материалах уголовных дел, расследованных органами по контролю за оборотом наркотических средств и психотропных веществ в 2012 году в связи с оборотом синтетических наркотических средств. С учетом существующих значительных правовых пробелов в правовой основе борьбы со сбытом наркотиков с использованием сети «Интернет» можно прогнозировать расширение масштабов организованной преступной деятельности в данном ее проявлении.

В настоящее время основными международными нормативными регуляторами являются Хартия глобального информационного общества, принятая в июле 2000 года в г. Окинаве, Конвенция ООН об использовании электронных сообщений в международных договорах, принятая в г. Нью-Йорке 23 ноября 2005 г., ${ }^{3}$ Европейская декларация о правах человека

\footnotetext{
${ }^{3}$ Россия приняла решение подписать Конвенцию. См.: распоряжение Правительства Российской Федерации от 27 декабря 2006 г. № 1821-р//С3 РФ. 2007. № 1. Ч. II. Ст. 346.
} 


\section{Политика и общество 4 (112) • 2014}

и верховенстве права в информационном обществе 2005 года, Будапештская Конвенция о киберпреступности 2001 года, ${ }^{4}$ Соглашение между станами СНГ о сотрудничестве в области информации от 9 октября 1992 г., Декларация принципов построения информационного общества 2003 года и План действий Тунисского обязательства 2005 года, принятый Всемирным саммитом по информационному обществу, а также договору между провайдерами России, США, Франции, Германии и других государств в сфере заключения и исполнения сделок, контрактов, оказания интернет-услуг.

На проходившей с 12 по 19 апреля 2010 г. в Бразилии (г. Сальвадоре) ХІІ Конгресс ООН по предупреждению преступности и уголовному правосудию Россия, «Группа 77» и Китай активно отстаивали идею разработки международной универсальной конвенции по киберпреступности. ${ }^{5}$ В итоге международному сообществу удалось достичь договоренности о закреплении в Сальвадорской декларации рекомендации об учреждении Комиссией ООН по предупреждению преступности и уголовному правосудию межправительственной рабочей группы открытого состава по проблематике киберпреступности с мандатом, предусматривающим, в том числе выработку предложений в отношении новых международных правовых мер по противодействию киберпреступности (пункт 42 указанной Декларации).

На тридцать шестом пленарном заседании Межпарламентской Ассамблеи государств-участников СНГ был принят Модельный закон «Об основах регулирования Интернета» (постановление № 36-9 от 16 мая 2011 г.), установивший принципы и определивший основные направления регулирования отношений, связанных с использованием сети «Интернет», а также порядок государственной поддержки развития сети «Интернет», отношения и функции участников регулирования сети «Интернет». ${ }^{6}$

Безусловно, эффективное противодействие киберпреступности, связанной с незаконным оборотом нар-

Текст Конвенции официально в России не опубликован (см. в справочной правовой системе «Консультант Плюс»).

${ }^{4}$ Конвенция о преступности в сфере компьютерной информации (ETS № 185). Текст Конвенции официально в России не опубликован (см. в справочной правовой системе «Консультант Плюс»).

${ }^{5}$ URL: http://www/ifap.ru/ofdocs/eu/dhrrlis.pdf.

${ }^{6}$ Дипломатический вестник. 2000. № $8.51 \mathrm{c}$. котиков, предусматривает, прежде всего, консолидированные международные усилия, имеющие сегодня очевидный резерв. Однако это не означает отсутствие перспективной работы у российского законодателя в текущий период времени. При всей актуальности вопроса на российском правовом пространстве до настоящего времени не выработано ни единого понятийного аппарата, ни эффективного механизма борьбы с преступной деятельностью, осуществляемой с использованием сети «Интернет».

В российском законодательстве не существует нормативного определения кибернетического пространства. Киберпространство может быть рассмотрено лишь в толковании Верховного Суда Соединенных Штатов Америки как «уникальная среда, не расположенная в географическом пространстве, но доступная каждому в любой точке мира, посредством доступа в Интернет». ${ }^{7}$ Между тем, данное понятие является одним из основных понятий института информационного права в международно-правовых отношениях. В частности, в г. Будапеште 23 ноября 2001 г. была заключена Конвенция о преступности в сфере компьютерной информации (ETS № 185), в которой использован производное от «киберпространство» понятие - «киберпреступность».

Не утверждены и иные необходимые российской правоприменительной практике понятия. В частности, отсутствием понятийного аппарата обусловлена сложность определения события правонарушения и правильной квалификации содеянного, установления круга лиц, привлекаемых к юридической ответственности, а также фиксации доказательств, оценки их допустимости и достоверности.

У российского правоприменителя существуют проблемы в проведении сложных процедур по просмотру протоколов доступа, проверке учетных записей провайдеров, определению телефонных номеров и их владельцев, просмотру содержимого серверов, установлению владельцев серверов, зачастую находящихся в разных странах, так как экстерриториальность сети «Интернет» позволяет размещать противоправную информацию на территориях других государств, к примеру, заключив договор хостинга с провайдером, находящимся за пределами Российской Федерации.

Существующий правовой механизм борьбы с распространением наркотиков с использованием сети

\footnotetext{
${ }^{7}$ Информационный вестник Совета глав государств и Совета глав Правительств СНГ «Содружество». № 1(37). 138 с.
} 
«Интернет» объективно требует совершенствования. В настоящее время у операторов связи (провайдеров) отсутствует обязанность приостанавливать или прекращать оказание услуг связи абоненту или пользователю услугами связи при предоставлении или распространении данными субъектами запрещенной информации по собственной инициативе.

Согласно пункту 47 Правил оказания телематических услуг связи, утвержденных постановлением Правительства Российской Федерации от 10 сентября 2007 г. № 575, в случаях, предусмотренных российским законодательством, или в случае нарушения абонентом требований, установленных договором, оператор связи имеет право приостановить оказание телематических услуг связи до устранения нарушения, письменно уведомив об этом абонента. Если абонент не устранит нарушение в течение 6 месяцев с даты получения им письменного уведомления оператора связи о намерении приостановить оказание телематических услуг связи, оператор связи вправе расторгнуть договор в одностороннем порядке.

Данная норма права основана на положении части 3 статьи 44 Федерального закона «О связи» от 7 июля 2003 г. № 126-Ф3, согласно которому «в случае нарушения пользователем услугами связи требований, установленных настоящим Федеральным законом, правилами оказания услуг связи или договором об оказании услуг связи, в том числе нарушения сроков оплаты оказанных ему услуг связи, определенных условиями договора об оказании услуг связи, оператор связи имеет право приостановить оказание услуг связи до устранения нарушения, за исключением случаев, установленных настоящим Федеральным законом». На основании приведенной нормы у оператора связи (провайдера) есть право по собственной инициативе приостанавливать или прекращать оказание телематических услуг связи, но не императивная обязанность.

В этой связи еще в 2011 году Федеральной службой Российской Федерации по контролю за оборотом наркотиков инициировано межведомственное обсуждение вопросов совершенствования действующего Федерального закона «О связи» от 7 июля 2003 г. № 126-Ф3 в части возложения дополнительных обязанностей на операторов связи. Однако указанная инициатива не нашла поддержки в Минкомсвязи России.

С учетом общественной опасности деяний, связанных с незаконным оборотом наркотиков с ис- пользованием сети «Интернет», были разработаны и внесены Федеральным законом «О внесении изменений в отдельные законодательные акты Российской Федерации» от 1 марта 2012 г. № 18-Ф3 дополнения в квалификационные признаки деяния, регламентированного частью 2 «Сбыт наркотических средств, психотропных веществ или их аналогов» статьи 228.1 «Незаконное производство, сбыт или пересылка наркотических средств, психотропных веществ или их аналогов, а также незаконный сбыт или пересылка растений, содержащих наркотические средства или психотропные вещества, либо их частей, содержащих наркотические средства или психотропные вещества» Уголовного кодекса Российской Федерации: «б) с использованием средств массовой информации либо электронных или информационно-телекоммуникационных сетей (включая сеть «Интернет»)».

Вместе с тем принятых мер объективно не достаточно, так как они не устраняют основных существующих правовых проблем понятийного аппарата и механизма работы по выявлению и пресечению преступлений рассматриваемой категории.

В целях эффективной организации борьбы с незаконным оборотом наркотиков и их пропагандой с использованием сети «Интернет» целесообразно провести следующую работу.

- Разработать закон Российской Федерации «О сети «Интернет»», в котором утвердить понятийный аппарат и установить основные принципы борьбы с использование данного ресурса в целях совершения преступлений, связанных с незаконным оборотом наркотиков.

- В действующем российском законодательстве предусмотреть нормы, регламентирующие обязанности провайдера:

контролировать содержание информации, размещенной на регулируемых ими ресурсах, а также обязанность поставщиков коммуникативных услуг хранить в течение определенного срока и представлять уполномоченным правоохранительным органам соответствующую информацию;

блокировать доступ к ресурсам в случае, если сайт располагается на иностранном сервере, но его содержание противоречит российскому законодательству;

своевременно пресекать распространение преступной информации и своевременно уведомлять об этом правоохранительные органы. 


\section{Политика и общество 4 (112) • 2014}

При этом нормативные изменения должны вноситься по принципу, в соответствии с которым провайдер несет ответственность за качество информации, размещенной на его сервере, в случае если:

данная информация размещалась по его инициативе и (или) за его счет;

провайдер был осведомлен или имел возможность быть осведомленным о содержании информации, размещенной на его сервере;

преднамеренные или непрофессиональные (противоречащие профессиональной подготовке, работе и возможности) действия провайдера повлекли размещение незаконной информации на его сайте;

неисполнение требований законодательства по пресечению распространения противоправной информации определенного законодательного характеpa, а также требований уполномоченных компетентных органов по приостановлению или прекращению деятельности сайта.

В группе «Г» нормативных правовых актов, содержащих нормы, составляющие систему воздействия на процессы детерминации и причинности организованной преступности, связанной с незаконным оборотом наркотиков в наркопритонах, наиболее актуальными остаются вопросы совершенствования нормативных правовых актов, регламентирующих организацию профилактического наблюдения в наркологических учреждениях за лицами, замеченными в немедицинском потреблении наркотиков, социальной реабилитации бывших наропотребителей, а также регламентирующих организацию медицинского освидетельствования.

В частности, согласно действующей Инструкции о порядке диспансерного учета больным хроническим алкоголизмом, наркоманиями, токсикоманиями и профилактического наблюдения лиц, злоупотребляющих алкоголем, замеченных в немедицинском потреблении наркотических и одурманивающих средств без клинических проявлений заболевания, утвержденной приказом Минздрава СССР от 12 сентября 1988 г. № 704 «О сроках диспансерного наблюдения больных алкоголизмом, наркоманиями и токсикоманиями», за лицами, обратившимися за наркологической помощью самостоятельно или по направлению органов внутренних дел Российской Федерации, у которых злоупотребление наркотиками не сопровождается клиническими проявлениями заболевания, организуется профилактическое наблюдение. Целью профилактического на- блюдения является предупреждение развития у лица наркомании. Однако данные нормативные положения существуют лишь на бумаге, оставаясь на практике нереализованными, так как существующие учеты Минздрава России предполагают лишь учет лиц с диагнозом «наркомания» и лиц, употребляющих наркотики с вредными последствиями. В первом случае, наркопотребитель уже болен, во втором - у него наступило расстройство здоровья вследствие потребления наркотиков, например, появилось заболевание системы органов кровообращения, что также характеризует далеко не первоначальную стадию наркопотребления.

В этих условиях не реализуется цель о предупреждении развития заболевания «наркомания», заложенная не только в указанный приказ, но и в федеральные законы. В частности, пунктом 6 статьи 2 Федерального закона от 21 ноября 2011 г. № 323-Ф3 «Об основах охраны здоровья граждан в Российской Федерации» регламентировано, что профилактика комплекс мероприятий, направленных на сохранение и укрепление здоровья и включающих в себя формирование здорового образа жизни, предупреждение возникновения и (или) распространения заболеваний, их раннее выявление, выявление причин и условий их возникновения и развития.

Необходимо создать в органах исполнительной власти субъектов Российской Федерации в сфере здравоохранения нормативно закрепленную систему учета наркопотребителей, адекватную наркоситуации, то есть включающую не только учет лиц, у которых пагубное пристрастие уже переросло в наркозависимость или наступили вредные последствия для их здоровья, но и учет лиц, допускающих немедицинское потребление наркотиков без указанных последствий в целях организации за ними профилактического наблюдения.

Работа по созданию нормативно регламентированной системы адекватного учета наркопотребителей в органах исполнительной власти субъектов Российской Федерации в сфере здравоохранения должна вестись параллельно с работой по созданию правового механизма информирования органов исполнительной власти субъектов Российской Федерации в сфере здравоохранения о выявленных лицах, совершивших административные правонарушения, связанные с немедицинским потреблением наркотиков. Так как это два элемента единого механизма, который необходимо создать. 


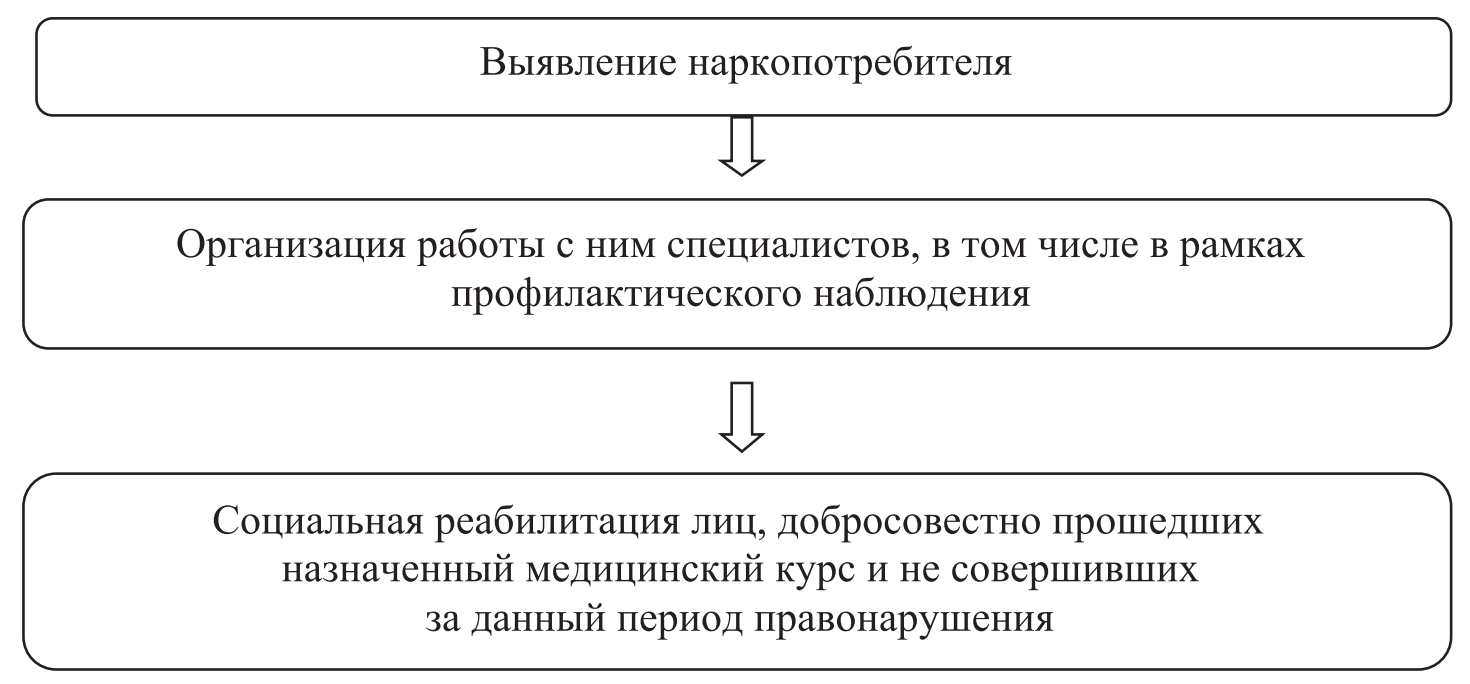

В предложенном на схеме 3 механизме все три этапа в настоящее время требуют различной проработки. На первом этапе правовой пробел очевиден в организации работы по информированию органов исполнительной власти субъектов Российской Федерации в сфере здравоохранения о лицах, совершивших административные правонарушения, связанные с немедицинским потреблением наркотиков, на втором - в организации профилактического наблюдения за данными лицами, на третьем - в целом в правовых основах социальной реабилитации лиц, добросоветсно прошедших назначенный медицинский курс и не совершивших за данный период административные правонарушения или преступления.

Так, Стратегией государственной антинаркотической политики Российской Федерации до 2020 года, утвержденной указом Президента Российской Федерации от 9 июня 2010 г. № 690, ${ }^{8}$ регламентировано содержание понятия реабилитации больных наркоманией, которая определяется как совокупность медицинских, психологических, педагогических, правовых и социальных мер, направленных на восстановление физического, психологического, духовного и социального здоровья, способности функционировать в об-

\footnotetext{
${ }^{8}$ Об утверждении Стратегии государственной антинаркотической политики Российской Федерации до 2020 года [Электронный ресурс] : указ Президента Российской Федерации от 9 июня 2010 г. № 690 : по состоянию на 01.06.2013. Доступ из справ.-правовой системы «Консультант Плюс».
}

ществе (реинтеграцию) без употребления наркотиков. Однако далее единое правовое толкование отсутствует и на практике напрямую зависит от позиции конкретных должностных лиц. Наряду с указанным, законодателем не предусмотрена профессиональная реабилитация, предполагающая предоставление услуг по профессиональной ориентации, профессиональной подготовке, переподготовке и оказание содействия в трудоустройстве лицам, добросовестно прошедшим курс лечения и вставшим на путь исправления.

Таким образом, необходимость совершенствования действующей правовой основы борьбы с организованной преступностью, связанной с незаконным оборотом наркотиков в наркопритонах, очевидна. При этом на отдельных направлениях требуется разработка новых нормативных правовых актов, что в комплексе позволит совершенствовать правовую основу борьбы с данным явлением, оказывающим существенное негативное влияние на систему общественных отношений, разрушая их и провоцируя социальные взрывы.

\section{Библиография:}

1. Об утверждении Стратегии государственной антинаркотической политики Российской Федерации до 2020 года [Электронный ресурс]: указ Президента Российской Федерации от 9 июня 2010 г. № 690 : по состоянию на 01.06.2013. Доступ из справ.-правовой системы «Консультант Плюс». 


\section{Политика и общество 4 (112) • 2014}

2. Распоряжение Правительства Российской Федерации от 27 декабря 2006 г. № 1821-p//С3 РФ. 2007. № 1. Ч. II. Ст. 346. Текст Конвенции официально в России не опубликован (см. в справочной правовой системе «Консультант Плюс»).

3. Конвенция о преступности в сфере компьютерной информации (ETS № 185). Текст Конвенции официально в России не опубликован (см. в справочной правовой системе «Консультант Плюс»).

4. Белоцерковский С.Д. Система правового регулирования борьбы с организованной преступностью и научные основы ее оптимизации: Монография. - М. : Российская криминологическая ассоциация, 2011. 257, 258, 392 с.

5. Дипломатический вестник. 2000. № 8. 51 с.

6. Информационный вестник Совета глав государств и Совета глав Правительств СНГ «Содружество». № 1(37). $138 \mathrm{c}$.

7. URL: http://www/ifap.ru/ofdocs/eu/dhrrlis.pdf.

8. Гуляихин В.Н. Правовой менталитет российских граждан // NB: Вопросы права и политики. - 2012. - 4. - C. 108-133. URL: http://www.e-notabene.ru/lr/ article_310.html

9. Попов Е.А. Человек, общество и наркотические средства: социальный, общеправовой и криминологический аспекты отношения // NB: Вопросы права и политики. - 2012. - 1. - C. 35-68. URL: http://www.e-notabene.ru/lr/article_48.html

10. Кухарук В.В. Отсрочка отбывания наказания больным наркоманией: вопросы теории и реализации // NB: Вопросы права и политики. - 2013. - № 1. - C.148-165. DOI: 10.7256/2305-9699.2013.1.366. URL: http://e-notabene.ru/lr/article_366.htm

11. Кухарук В.В. Опасные воздействия на психические функции человека и проблемы их уголовноправового регулирования // NB: Вопросы права и политики. - 2013. - № 5. - C.64-82. DOI: 10.7256/2305-9699.2013.5.783. URL: http://e-notabene.ru/lr/article_783.html

12. Е. А. Попов. Особенности деятельности служб, связанных с противодействием наркотической зависимости населения. // Право и политика.-2012. - № 10. - С. 1701-1706.

13. Г. М. Горничар. Пробелы в статье 230 УК РФ: склонение к потреблению наркотических средств или психотропных веществ. // Право и политика. - 2011. - № 9. - С. 1465-1469.

14. В. В. Савченко. Наркотизации молодежи российской провинции как угроза национальной безопасности страны.. // Национальная безопасность / nota bene. - 2010. - № 11 .

15. Д.В. Бахарев, А.В. Жигалова. Проблемы и перспективы организации противодействия незаконному обороту наркотиков в заведениях досуга и отдыха молодежи (опыт межрегионального исследования). // Национальная безопасность / nota bene. -2009 . - № 5

\section{References (transliteration):}

1. Belotserkovskii S.D. Sistema pravovogo regulirovaniya bor'by s organizovannoi prestupnost'yu i nauchnye osnovy ee optimizatsii: Monografiya. M. : Rossiiskaya kriminologicheskaya assotsiatsiya, 2011. 257, 258, 392 s.

2. Gulyaikhin V.N. Pravovoi mentalitet rossiiskikh grazhdan // NB: Voprosy prava i politiki. - 2012. 4. - C. 108-133. URL: http://www.e-notabene.ru/lr/ article_310.html

3. Popov E.A. Chelovek, obshchestvo i narkoticheskie sredstva: sotsial'nyi, obshchepravovoi i kriminologicheskii aspekty otnosheniya // NB: Voprosy prava i politiki. - 2012. - 1. - C. 35-68. URL: http:// www.e-notabene.ru/lr/article 48.html

4. Kukharuk V.V. Otsrochka otbyvaniya nakazaniya bol'nym narkomaniei: voprosy teorii i realizatsii // NB: Voprosy prava i politiki. - 2013. - № 1. - S.148165. DOI: 10.7256/2305-9699.2013.1.366. URL: http://e-notabene.ru/lr/article_366.htm

5. Kukharuk V.V. Opasnye vozdeistviya na psikhicheskie funktsii cheloveka i problemy ikh ugolovno-pravovogo regulirovaniya // NB: Voprosy prava i politiki. - 2013. - № 5. - S.64-82. DOI: 10.7256/2305-9699.2013.5.783. URL: http://e-notabene.ru/lr/article_783.html

6. E. A. Popov. Osobennosti deyatel'nosti sluzhb, svyazannykh s protivodeistviem narkoticheskoi zavisimosti naseleniya. // Pravo i politika. - 2012. - № 10. - C. 1701-1706.

7. G. M. Gornichar. Probely v stat'e 230 UK RF: sklonenie $\mathrm{k}$ potrebleniyu narkoticheskikh sredstv ili psikhotropnykh veshchestv. // Pravo i politika. - 2011. № 9. - C. 1465-1469.

8. V. V. Savchenko. Narkotizatsii molodezhi rossiiskoi provintsii kak ugroza natsional'noi bezopasnosti strany.. // Natsional'naya bezopasnost' / nota bene. -2010 . - № 11 . 
9. D.V. Bakharev, A.V. Zhigalova. Problemy i perspektivy organizatsii protivodeistviya nezakonnomu oborotu narkotikov $\mathrm{v}$ zavedeniyakh dosu- ga i otdykha molodezhi (opyt mezhregional'nogo issledovaniya). // Natsional'naya bezopasnost' / nota bene. -2009 . - № 5 